\title{
Limnobacter litoralis sp. nov., a thiosulfate- oxidizing, heterotrophic bacterium isolated from a volcanic deposit, and emended description of the genus Limnobacter
}

Correspondence
Hiroyuki Ohta
hohta@mx.ibaraki.ac.jp

\author{
Hongsheng Lu, ${ }^{1,2} \dagger$ Yoshinori Sato, ${ }^{2,3}$ Reiko Fujimura, ${ }^{1,2}$ \\ Tomoyasu Nishizawa, ${ }^{1}$ Takashi Kamijo ${ }^{4}$ and Hiroyuki Ohta ${ }^{1,2}$ \\ ${ }^{1}$ Ibaraki University College of Agriculture, 3-21-1 Chuou, Ami, Ibaraki 300-0393, Japan \\ ${ }^{2}$ United Graduate School of Agricultural Science, Tokyo University of Agriculture and Technology, \\ 3-5-8 Saiwai, Fuchu, Tokyo 183-8509, Japan \\ ${ }^{3}$ Institute for Global Change Adaptation Science, Ibaraki University, 2-1-1 Bunkyo, Mito, Ibaraki \\ 310-8512, Japan \\ ${ }^{4}$ Graduate School of Life and Environmental Science, University of Tsukuba, 1-1-1 Tennodai, \\ Tsukuba, Ibaraki 305-8572, Japan
}

\begin{abstract}
A Gram-negative, aerobic, heterotrophic bacterium, designated $\mathrm{KP} 1-19^{\top}$, was isolated from a 22year-old volcanic deposit at a site lacking vegetation on the island of Miyake, Japan. Strain KP1$19^{\top}$ was able to use thiosulfate (optimum concentration $10 \mathrm{mM}$ ) as an additional energy source. $16 \mathrm{~S}$ rRNA gene sequence analysis indicated that strain $\mathrm{KP} 1-19^{\top}$ was closely related to Limnobacter thiooxidans CS-K2 ${ }^{\top}$ within the class Betaproteobacteria (97.7\% 16S rRNA gene sequence similarity). The cellular fatty acid profile was characteristic of the genus Limnobacter: the major fatty acids $(>5 \%)$ were $\mathrm{C}_{16: 0}, \mathrm{C}_{16: 1} \omega 7 \mathrm{c}$ and $\mathrm{C}_{18: 1} \omega 7 \mathrm{c}$ and minor amounts of $\mathrm{C}_{10: 0}$ $3-\mathrm{OH}$ were also found. DNA-DNA relatedness between strain $\mathrm{KP} 1-19^{\top}$ and $L$. thiooxidans $\mathrm{LMG}$ $19593^{\top}$ was $18 \%$. Therefore, strain $\mathrm{KP} 1-19^{\top}$ represents a novel species, for which the name Limnobacter litoralis sp. nov. is proposed. The type strain is KP1-19 ${ }^{\top}\left(=\mathrm{LMG} 24869^{\top}=\mathrm{NBRC}\right.$ $105857^{\top}=$ CIP $109929^{\top}$ ).
\end{abstract}

The genus Limnobacter, a member of the class Betaproteobacteria, was established to accommodate thiosulfateoxidizing heterotrophic bacteria isolated from sediment of the littoral zone of a freshwater lake (Spring et al., 2001). The genus Limnobacter comprises Gram-negative, polyhydroxybutyrate (PHB)-containing, non-spore-forming, strictly aerobic, oxidase- and catalase-positive, slightly curved rods, motile by single polar flagella. Carboxylic acids and amino acids are used as energy and carbon sources, but carbohydrates and polyols are not used. Thiosulfate is oxidized to sulfate in the presence of an organic carbon source, but autotrophic growth is not exhibited. The major fatty acids are

tPresent address: Shandong University of Science and Technology, Qianwangang Economic \& Technical Development Zone, Qingdao 266510, PR China.

Abbreviation: PHB, polyhydroxybutyrate.

The GenBank/EMBL/DDBJ accession numbers for the $16 \mathrm{~S}$ rRNA gene sequences of strains KP1-17, KP1-18, KP1-19 ${ }^{\top}, \mathrm{KP} 1-22$ and $\mathrm{KP} 1-23$ are $A B 366172-A B 366174, A B 366177$ and $A B 366178$, respectively.

A supplementary figure is available with the online version of this paper.
$\mathrm{C}_{18: 1} \omega 7 c, \mathrm{C}_{16: 1} \omega 7 c, \mathrm{C}_{16: 0}$ and $\mathrm{C}_{10: 0}$ 3-OH. Until now, only the type species, Limnobacter thiooxidans, has been described.

Strain KP1-19 $9^{\mathrm{T}}$ was isolated from a 22 -year-old volcanic deposit at the Nippana site $\left(34^{\circ} 02^{\prime} 50.7^{\prime \prime} \mathrm{N} 139^{\circ} 30^{\prime} 02.1^{\prime \prime}\right.$ E) on the island of Miyake, Japan, on the western rim of the Pacific Ocean (Lu et al., 2008). The isolate was cultured on 100-fold-diluted nutrient agar and characterized as a member of the genus Limnobacter by comparative $16 \mathrm{~S}$ rRNA gene sequence analysis (Lu et al., 2008). Strain KP1$19^{\mathrm{T}}$ did not grow chemolithoautotrophically with $\mathrm{H}_{2}, \mathrm{O}_{2}$ or $\mathrm{CO}_{2}$ but grew chemolithoheterotrophically with thiosulfate (optimum concentration $10 \mathrm{mM}$ ) in succinate/ mineral medium [containing $0.27 \%(\mathrm{w} / \mathrm{v})$ sodium succinate, $0.01 \%(\mathrm{w} / \mathrm{v})$ yeast extract and various mineral salts; $\mathrm{Lu}$ et al., 2008], which has been described for the genus Limnobacter (Spring et al., 2001). Strain KP1-19 $9^{\mathrm{T}}$ was characterized as an oligotroph (Ohta \& Hattori, 1983; Ohta et al., 2004) by its ability to grow in very low-nutrient media such as 10000 -fold-diluted nutrient broth. This growth characteristic appears to represent a selective advantage in organic substrate-deficient environments 
such as recently formed volcanic deposits (King, 2007; King et al., 2008).

For phenotypic tests and chemotaxonomic and molecular systematic characterization, strain $\mathrm{KP} 1-19^{\mathrm{T}}$ was cultured in 10 -fold-diluted nutrient broth (NB) [containing $0.1 \%(\mathrm{w} /$ v) meat extract (Kyokuto Seiyaku), $0.1 \%(\mathrm{w} / \mathrm{v})$ polypeptone (Nihon Seiyaku) and $0.05 \%(\mathrm{w} / \mathrm{v}) \mathrm{NaCl}, \mathrm{pH} 7.0]$. Conditions for growth were determined at $30{ }^{\circ} \mathrm{C}$ and $\mathrm{pH}$ 7.0, unless otherwise stated, for 2 weeks at 4, 8, 10, 2836 (at intervals of $4{ }^{\circ} \mathrm{C}$ ) and $36-46{ }^{\circ} \mathrm{C}\left(\right.$ at intervals of $2{ }^{\circ} \mathrm{C}$ ), with $0.05,0.1,0.5,1.0$ and $5-10 \%(\mathrm{w} / \mathrm{v}) \mathrm{NaCl}$ (at intervals of $1 \% \mathrm{NaCl}$ ) and at $\mathrm{pH} 5.5-10.5$ (at intervals of $0.5 \mathrm{pH}$ units). Growth at different $\mathrm{pH}$ and the maximum specific growth rate $\left(\mathrm{h}^{-1}\right)$ at different temperatures and $\mathrm{NaCl}$ concentrations were determined by measuring optical density $\left(\mathrm{OD}_{660}\right)$. For the examination of autotrophic growth, the strain was cultured at $35{ }^{\circ} \mathrm{C}$ in mineral salt medium (Sato et al., 2004) supplemented with either sodium thiosulfate $(10$ or $50 \mathrm{mM})$ or elemental sulfur $(1 \%, \mathrm{w} / \mathrm{v})$. Thiosulfate- and sulfur-oxidizing autotrophic growth was determined by following optical density and $\mathrm{pH}$ change of the medium. The presence of PHB was examined microscopically by staining with a basic oxazine dye, Nile blue A (Ostle \& Holt, 1982). Oxidase and catalase tests were carried out as described previously (Ohta \& Hattori, 1983). Morphology of cells from the exponential growth phase was examined under a light microscope (BX51; Olympus) and a transmission microscope (JEM-2000 FX II; JEOL) as described previously (Ushiba et al., 2003). The ability to grow anaerobically was tested on R2A medium (van der Linde et al., 1999) at $30{ }^{\circ} \mathrm{C}$ for 1 week using a BBL GasPak anaerobic system. Additional phenotypic characteristics were determined using API 20NE (bioMérieux) and Biolog GN2 MicroPlates (Hayward), according to the manufacturers' instructions. As a reference strain for DNA-DNA hybridization tests and cellular fatty acid profiling, L. thiooxidans LMG $19593^{\mathrm{T}}$ was obtained from the BCCM/LMG culture collection, Gent, Belgium.

Cellular fatty acid methyl esters were prepared by heating dried cells in anhydrous methanolic $\mathrm{HCl}$ at $100{ }^{\circ} \mathrm{C}$ for $3 \mathrm{~h}$ (Ikemoto et al., 1978) and then analysed by GLC with a GC-14A gas chromatograph and a ULBON HR-SS-10 capillary column $(0.23 \mathrm{~mm} \times 50 \mathrm{~m}$; Shimadzu $)$. Fatty acid methyl ester peaks were identified using a bacterial acid methyl ester mixture (Supelco) and comparing retention times against those of standard compounds. Isoprenoid quinones were extracted and analysed by HPLC as described by Komagata \& Suzuki (1987) with conditions and preparation of standards as described previously by Ohta et al. (2003). G + C content was determined by hydrolysing the DNA enzymically and quantifying the nucleotides by HPLC (Tamaoka \& Komagata, 1984). DNA-DNA hybridization tests were carried out with photobiotin-labelled probes in microplate wells (Ezaki et al., 1989) using a Wallac 1420 ARVOsx multilabel counter for chemiluminescence measurements. For enzymic development, alkaline phosphatase-streptavidin conjugate (Vector) was used with CDP-Star (Tropix) as the substrate. Nearly complete $16 \mathrm{~S}$ rRNA gene sequences of strain KP1-19 ${ }^{\mathrm{T}}$ and four additional strains (KP1-17, KP118, KP1-22 and KP1-23) were obtained as described previously (Sato et al., 2006). For phylogenetic analysis, closely related $16 \mathrm{~S}$ rRNA gene sequences were retrieved from public databases using BLAST (Pearson \& Lipman, 1988). The sequences were aligned and a phylogenetic tree was produced with the neighbour-joining method (Saitou \& Nei, 1987) in Clustal $w$ (Thompson et al., 1994). The tree was visualized using TreeView version 1.6.6 (Page, 1996).

Cells of strain KP1-19 ${ }^{\mathrm{T}}$ were found to be Gram-negative, catalase- and oxidase-positive, non-spore-forming, slightly curved rods $(0.4-0.6 \times 1-3 \mu \mathrm{m})$ that were motile with a polar flagellum (Supplementary Fig. S1, available in IJSEM Online). Cells contained PHB granules and fluoresced with a bright orange colour when stained with Nile blue A. The strain did not grow anaerobically on R2A medium and did not reduce nitrate. Strain KP1-19 ${ }^{\mathrm{T}}$ did not grow chemolithoautotrophically with thiosulfate and sulfur and did not use any of the 31 tested carbohydrates (Table 1). These phenotypic characteristics are identical to those reported for the genus Limnobacter (Spring et al., 2001). Strain KP1$19^{\mathrm{T}}$ did not grow at 8 or $46{ }^{\circ} \mathrm{C}$ and its optimum growth temperature was $38-42{ }^{\circ} \mathrm{C}$, suggesting that strain $\mathrm{KP} 1-19^{\mathrm{T}}$ is more mesophilic than $L$. thiooxidans (range $4-38{ }^{\circ} \mathrm{C}$; Spring et al., 2001). The optimum $\mathrm{NaCl}$ concentration for growth was $0.5 \% \mathrm{NaCl}$, and the growth rate with $5 \% \mathrm{NaCl}$ was about half that with $0.5 \% \mathrm{NaCl}$. Strain $\mathrm{KP} 1-19^{\mathrm{T}}$ could grow with $8 \%$ but not with $9 \% \mathrm{NaCl}$. Other characteristics of strain $\mathrm{KP} 1-19^{\mathrm{T}}$ are given in the species description and differences between strain $\mathrm{KP} 1-19^{\mathrm{T}}$ and $L$. thiooxidans LMG $19593^{\mathrm{T}}$ are shown in Table 1.

The cellular fatty acid profiles of strain KP1-19 $9^{\mathrm{T}}$ and $L$. thiooxidans LMG $19593^{\mathrm{T}}$ were very similar, the fatty acids in both strains being $\mathrm{C}_{16: 0}$ (39.9 and $24.2 \%$, respectively), $\mathrm{C}_{16: 1} \omega 7 c(21.4$ and $38.8 \%), \mathrm{C}_{18: 1} \omega 7 c(20.0$ and $27.3 \%)$, $\mathrm{C}_{10: 0} 3-\mathrm{OH}$ (4.9 and $\left.2.7 \%\right), \mathrm{C}_{18: 0}(3.4$ and $4.8 \%)$ and $\mathrm{C}_{14: 0}(1.1$ and $2.3 \%)$. Strain KP1-19 ${ }^{\mathrm{T}}$ also contained two additional fatty acids, which were tentatively identified as $\mathrm{C}_{17: 0}$ cyclo $(6.9 \%)$ and $\mathrm{C}_{19: 0}(2.5 \%)$. The major respiratory quinone of strain $\mathrm{KP} 1-19^{\mathrm{T}}$ was ubiquinone Q-8 and the DNA G + C content was 59 mol\%, which was slightly higher than that reported for $L$. thiooxidans (55 mol\%; Spring et al., 2001).

Our previous study (Lu et al., 2008) determined the nearly complete 16S rRNA gene sequence (1495 nt) of strain KP1$19^{\mathrm{T}}$ and revealed that the isolate was associated with the family Burkholderiaceae by phylogenetic analysis. In addition, Lu et al. (2008) showed that strain KP1-19 and 36 other related isolates from the volcanic deposit shared $\geqslant 99.3 \% 16 \mathrm{~S}$ rRNA gene sequence similarity (about $600 \mathrm{nt}$ ). Therefore, in this study, four other isolates (KP117, KP1-18, KP1-22 and KP1-23) were randomly selected 
Table 1. Differential characteristics of strain $\mathrm{KP} 1-19^{\top}$ and $L$. thiooxidans LMG $19593^{\top}$

Data were taken from this study unless otherwise stated. Both strains are positive for $\beta$-glucosidase and $\beta$-galactosidase and assimilation of Tweens 40 and 80 , acetate, DL-lactate and succinate. Both strains are negative for protease, indole production and assimilation of $\alpha$ cyclodextrin, dextrin, glycogen, $\mathrm{N}$-acetyl-D-galactosamine, $\mathrm{N}$-acetyl-Dglucosamine, adonitol, L-arabinose, D-arabitol, D-cellobiose, i-erythritol, D-fructose, L-fucose, D-galactose, gentiobiose, $\alpha$-D-glucose, myo-inositol, lactose, lactulose, maltose, D-mannitol, D-mannose, melibiose, methyl $\alpha$-D-glucoside, D-psicose, D-raffinose, L-rhamnose, D-sorbitol, sucrose, trehalose, turanose, xylitol, cis-aconitic acid, citric acid, D-galactonic acid lactone, D-galacturonic acid, D-gluconic acid, D-glucosaminic acid, D-glucuronic acid, $\alpha$-hydroxybutyric acid, $\gamma$-hydroxybutyric acid, $p$ hydroxyphenylacetic acid, itaconic acid, $\alpha$-ketobutyric acid, $\alpha$-ketovaleric acid, malonic acid, propionic acid, quinic acid, D-saccharic acid, sebacic acid, bromosuccinic acid, succinamic acid, glucuronamide, Lalaninamide, D-alanine, L-alanine, L-alanyl glycine, L-asparagine, glycyl L-aspartic acid, glycyl L-glutamic acid, L-histidine, hydroxy-L-proline, L-leucine, L-ornithine, L-phenylalanine, L-proline, L-pyroglutamic acid, D-serine, L-serine, L-threonine, DL-carnitine, $\gamma$-aminobutyric acid, urocanic acid, inosine, uridine, thymidine, phenylethylamine, putrescine, 2-aminoethanol, 2,3-butanediol, glycerol, DL- $\alpha$-glycerol phosphate, $\alpha$-D-glucose 1-phosphate, D-glucose 6-phosphate, n-capric acid and adipic acid. + , Positive; $\mathrm{W}$, weakly positive; - , negative.

\begin{tabular}{|lcc|}
\hline Characteristic & KP1-19 & $\begin{array}{c}\text { L. thiooxidans } \\
\text { LMG }^{\text {19593 }}{ }^{\mathbf{T}}\end{array}$ \\
\hline Growth at $4{ }^{\circ} \mathrm{C}$ & - & + \\
Growth at $44{ }^{\circ} \mathrm{C}$ & + & - \\
Arginine dihydrolase & + & - \\
Urease & + & - \\
Assimilation of: & $-{ }^{a}$ & $+^{a}$ \\
L-Aspartate & $\mathrm{W}$ & - \\
Formate & $-{ }^{a}$ & $+^{a}$ \\
Fumarate & $-{ }^{a}$ & $+^{a}$ \\
L-Glutamate & + & $\mathrm{W}^{a}$ \\
$\beta$-Hydroxybutyrate & $\mathrm{W}$ & - \\
2-Oxoglutarate & 59 & $55^{b}$ \\
DNA G+C content $(\mathrm{mol} \%)$ & & \\
\hline
\end{tabular}

${ }^{\star}$ Data from: $a$, Lu et al. (2008); b, Spring et al. (2001).

and their almost full-length $16 \mathrm{~S}$ rRNA gene sequences were determined. The five isolates shared $\geqslant 99.7 \% 16 \mathrm{~S}$ rRNA gene sequence similarity (1412 nt). As shown in Fig. 1, the five isolates formed a clade that represented a sibling taxon of $L$. thiooxidans $\mathrm{CS}-\mathrm{K} 2^{\mathrm{T}}$. $16 \mathrm{~S}$ rRNA gene sequence similarity between strain $\mathrm{KP} 1-19^{\mathrm{T}}$ and $L$. thiooxidans CS$\mathrm{K} 2^{\mathrm{T}}$ was $97.7 \%$. DNA-DNA relatedness between strain KP1 $19^{\mathrm{T}}$ and L. thiooxidans LMG $19593^{\mathrm{T}}$ was $18 \%$ (mean of two independent determinations: $20 \%$ with strain KP1$19^{\mathrm{T}}$ as the probe and $16 \%$ with the reciprocal experiment). This value is below the $70 \%$ cut-off for DNA-DNA relatedness that is a criterion for the assignment of bacterial strains to different genomic species (Wayne et al., 1987).

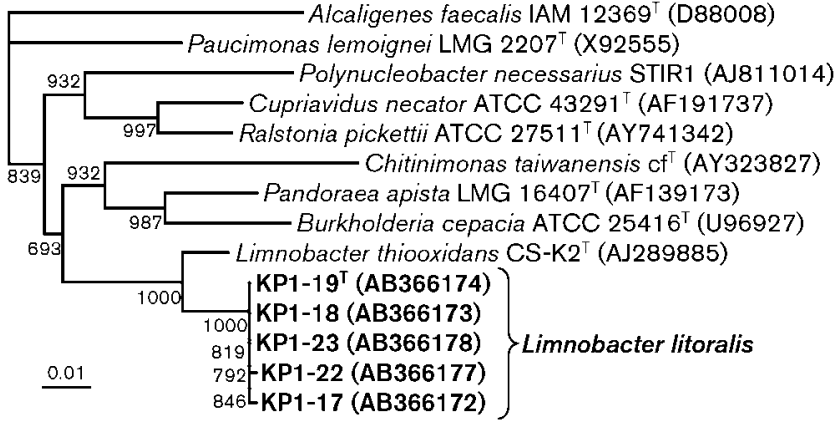

Fig. 1. Neighbour-joining phylogenetic tree based on 16S rRNA gene sequences (1319-1328 nt) showing the position of strains of Limnobacter litoralis sp. nov. within the family Burkholderiaceae. Bootstrap values $(>600)$ based on 1000 replicates are shown at branch nodes. The sequence of A/caligenes faecalis IAM $12369^{\top}$ was used as an outgroup. Bar, 0.01 substitutions per nucleotide position.

On the basis of phenotypic, genotypic and phylogenetic analysis, it is concluded that strain KP $1-19^{\mathrm{T}}$ represents a novel species of the genus Limnobacter, for which the name Limnobacter litoralis sp. nov. is proposed.

\section{Emended description of the genus Limnobacter Spring et al. 2001}

Main characteristics are as given by Spring et al. (2001), with the following amendments. Growth occurs between 4 and $44{ }^{\circ} \mathrm{C}$. The major ubiquinone is $\mathrm{Q}-8$.

\section{Description of Limnobacter litoralis sp. nov.}

Limnobacter litoralis (li.to.ra'lis. L. masc. adj. litoralis of or belonging to the seashore, referring to the supralitoral habitat from which the type strain was isolated).

Cells are Gram-negative, aerobic, non-sporulating, slightly curved rods $(0.4-0.6 \mu \mathrm{m}$ wide and $1-3 \mu \mathrm{m}$ long). Motile by a single polar flagellum. Colonies on 10 -fold-diluted nutrient agar after 1 week at $30{ }^{\circ} \mathrm{C}$ are $0.5-1.0 \mathrm{~mm}$ in diameter, circular, complete, convex, opaque and white. Grows at $10-44{ }^{\circ} \mathrm{C}$ (optimum $38-42{ }^{\circ} \mathrm{C}$ ) and $\mathrm{pH}$ 6.5-9.0 (optimum pH 7.0-7.5). Slightly halotolerant; grows with $0-8 \%(\mathrm{w} / \mathrm{v}) \mathrm{NaCl}$ (optimum $0.5 \% \mathrm{NaCl}$ ). Oligotrophic; grows in 10- to 10000 -fold-diluted nutrient broth but not in undiluted nutrient broth. Chemolithoheterotrophic growth occurs by oxidizing thiosulfate to sulfate as an additional energy source in the presence of organic substrates such as succinate; the optimum concentration of thiosulfate is about $10 \mathrm{mM}$. Catalase, oxidase, arginine dihydrolase and urease activities are present. Nitrate is not reduced to nitrite. Carbohydrates and amino acids, including L-aspartate and L-glutamate, are not used. Several carboxylic acids are assimilated: acetate, $\beta$-hydroxybutyrate, DL-lactate, succinate, formate (weakly) and 2oxoglutarate (weakly) are assimilated, but fumarate is not 
assimilated. The major ubiquinone is $\mathrm{Q}-8$. The major fatty acids are $\mathrm{C}_{16: 0}, \mathrm{C}_{16: 1} \omega 7 c, \mathrm{C}_{18: 1} \omega 7 c$ and $\mathrm{C}_{10: 0} 3-\mathrm{OH}$. The DNA $\mathrm{G}+\mathrm{C}$ content of the type strain is $59 \mathrm{~mol} \%$.

The type strain is $\mathrm{KP} 1-19^{\mathrm{T}}\left(=\mathrm{LMG} 24869^{\mathrm{T}}=\mathrm{NBRC}\right.$ $105857^{\mathrm{T}}=$ CIP $109929^{\mathrm{T}}$ ), isolated from a 22 -year-old volcanic deposit at the Nippana onshore site on the island of Miyake, Japan.

\section{Acknowledgements}

This study was supported in part by a grant-in-aid for scientific research from the Japan Society for the Promotion of Science (grant no. 17310018) and a financial donation from Yuuji Ushiba.

\section{References}

Ezaki, T., Hashimoto, Y. \& Yabuuchi, E. (1989). Fluorometric deoxyribonucleic acid-deoxyribonucleic acid hybridization in microdilution wells as an alternative to membrane filter hybridization in which radioisotopes are used to determine genetic relatedness among bacterial strains. Int J Syst Bacteriol 39, 224-229.

Ikemoto, S., Kathoh, K. \& Komagata, K. (1978). Cellular fatty acid composition in methanol-utilizing bacteria. J Gen Appl Microbiol 24, 41-49.

King, G. M. (2007). Chemolithotrophic bacteria: distributions, functions and significance in volcanic environment. Microbes Environ 22, 309-319.

King, G. M., Weber, C. F., Nanba, K., Sato, Y. \& Ohta, H. (2008). Atmospheric $\mathrm{CO}$ and hydrogen uptake and $\mathrm{CO}$ oxidizer phylogeny for Miyake-jima, Japan volcanic deposits. Microbes Environ 23, 299305.

Komagata, K. \& Suzuki, K. (1987). Lipid and cell-wall analysis in bacterial systematics. Methods Microbiol 19, 161-207.

Lu, H., Fujimura, R., Sato, Y., Nanba, K., Kamijo, T. \& Ohta, H. (2008). Characterization of Herbaspirillum- and Limnobacter-related strains isolated from young volcanic deposits in Miyake-jima Island, Japan. Microbes Environ 23, 66-72.

Ohta, H. \& Hattori, T. (1983). Agromonas oligotrophica gen. nov., sp. nov., a nitrogen-fixing oligotrophic bacterium. Antonie van Leeuwenhoek 49, 429-446.

Ohta, H., Ogiwara, K., Murakami, E., Takahashi, H., Sekiguchi, M., Koshida, K., Someya, T., Morishima, W., Rondal, J. D. \& other authors (2003). Quinone profiling of bacterial populations developed in the surface layer of volcanic mudflow deposits from Mt. Pinatubo (the Philippines). Soil Biol Biochem 35, 1155-1158.
Ohta, H., Hattori, R., Ushiba, Y., Mitsui, H., Ito, M., Watanabe, H., Tonosaki, A. \& Hattori, T. (2004). Sphingomonas oligophenolica sp. nov., a halo- and organo-sensitive oligotrophic bacterium from paddy soil that degrades phenolic acids at low concentrations. Int J Syst Evol Microbiol 54, 2185-2190.

Ostle, A. G. \& Holt, J. G. (1982). Nile blue A as a fluorescent stain for poly-beta-hydroxybutyrate. Appl Environ Microbiol 44, 238-241.

Page, R. D. M. (1996). TreeView: an application to display phylogenetic trees on personal computers. Comput Appl Biosci 12, 357-358.

Pearson, W. R. \& Lipman, D. J. (1988). Improved tools for biological sequence comparison. Proc Natl Acad Sci U S A 85, 2444-2448.

Saitou, N. \& Nei, M. (1987). The neighbor-joining method: a new method for reconstructing phylogenetic trees. Mol Biol Evol 4, 406425.

Sato, Y., Nishihara, H., Yoshida, M., Watanabe, M., Rondal, J. D. \& Ohta, H. (2004). Occurrence of hydrogen-oxidizing Ralstonia species as primary microorganisms in the Mt. Pinatubo volcanic mudflow deposits. Soil Sci Plant Nutr 50, 855-861.

Sato, Y., Nishihara, H., Yoshida, M., Watanabe, M., Rondal, J. D., Concepcion, R. N. \& Ohta, H. (2006). Cupriavidus pinatubonensis sp. nov. and Cupriavidus laharis sp. nov., novel hydrogen-oxidizing, facultatively chemolithotrophic bacteria isolated from volcanic mudflow deposits from Mt. Pinatubo in the Philippines. Int J Syst Evol Microbiol 56, 973-978.

Spring, S., Kämpfer, P. \& Schleifer, K. H. (2001). Limnobacter thiooxidans gen. nov., sp. nov., a novel thiosulfate-oxidizing bacterium isolated from freshwater lake sediment. Int J Syst Evol Microbiol 51, 1463-1470.

Tamaoka, J. \& Komagata, K. (1984). Determination of DNA base composition by reversed-phase high-performance liquid chromatography. FEMS Microbiol Lett 25, 125-128.

Thompson, J. D., Higgins, D. G. \& Gibson, T. J. (1994). CLUSTAL W: improving the sensitivity of progressive multiple sequence alignment through sequence weighting, position-specific gap penalties and weight matrix choice. Nucleic Acids Res 22, 4673-4680.

Ushiba, Y., Takahara, Y. \& Ohta, H. (2003). Sphingobium amiense sp. nov., a novel nonylphenol-degrading bacterium isolated from a river sediment. Int J Syst Evol Microbiol 53, 2045-2048.

van der Linde, K., Lim, B. T., Rondeel, J. M. M., Antonissen, L. P. M. T. $\&$ de Jong, G. M. T. (1999). Improved bacteriological surveillance of haemodialysis fluids: a comparison between tryptic soy agar and Reasoner's 2A media. Nephrol Dial Transplant 14, 2433-2437.

Wayne, L. G., Brenner, D. J., Colwell, R. R., Grimont, P. A. D., Kandler, O., Krichevsky, M. I., Moore, L. H., Moore, W. E. C., Murray, R. G. E. \& other authors (1987). International Committee on Systematic Bacteriology. Report of the ad hoc committee on reconciliation of approaches to bacterial systematics. Int J Syst Bacteriol 37, 463-464. 